\title{
Groundwater in Central America: Its Importance, Development and Use, with Particular Reference to Its Role in Irrigated Agriculture
}

\author{
Maureen Ballestero, Virginia Reyes \\ AND YAMILETH Astorga \\ Coordinator of Global Water Partnership of Central America (GWP-CA), \\ Oficial Técnico, GWP-Centroamérica, Correo electrónico
}

\section{Introduction}

Groundwater in the Central American region is currently being exploited mainly for human consumption and industrial activities. Utilization of groundwater for agriculture activities in Central America is still very limited when compared with that of other Latin American countries such as Mexico or Brazil, or, as highlighted elsewhere in this volume, with developing countries such as China or India. To date, agricultural activity in the region continues to rely on rainfall and, to a lesser extent, gravity irrigation. Nevertheless, during dry season in the Pacific region of Central America the exploitation of aquifers for irrigation in agriculture is increasing.

Unfortunately, almost no systematic data exist in any of the Central American countries about the potential volume of the main aquifers and of the existing demands on them. Still, in areas where use does exist, there are reports of a continual reduction in the water table levels, leading to concerns that the resource is already being used in a potentially inefficient and unsustainable manner. Likewise, although there have always been restrictions on certain high-risk activities in recharge areas and in important aquifers, a discussion is just beginning about protective measures to regulate urban expansion and limit the introduction of economic activities in these areas.

The objective of this chapter is to analyse the actual situation, using limited publicly available data coupled with interviews with key professionals, of groundwater in Central America, emphasizing the utilization of groundwater for agricultural production. The chapter is divided into four sections. The first contains a presentation of the Central American region and examines the availability of water in each of the seven countries, the levels of extraction and the 
amount of extracted water being used in various ways. The second gives a review of the use of water in agriculture in each of the countries of the region and of the irrigation techniques used. The third describes the existing institutional framework for groundwater management in Central America. The final section highlights the key issues for groundwater management in a region that has yet to experience a 'groundwater revolution' and the parallels with, and divergences from, regions where agricultural groundwater use is already more developed.

\section{Background}

Central America, the isthmus connecting the main body of North America with the South American continent, is made up of seven countries: Belize, Guatemala, Honduras, El Salvador, Nicaragua, Costa Rica and Panama (Fig. 6.1). The region has an area of over $500,000 \mathrm{~km}^{2}$ and a population of more than 37 million, growing at an annual rate of 2.4\% (GWP, 2005). Urbanization over the last 30 years has shifted the population balance, with nearly $53 \%$ of the people now living in areas officially considered to be urban, and the remaining $47 \%$ residing in rural areas.

The Central American region shares a volcanic chain that extends from the north to the south and serves to divide the region's waters into Atlantic and Pacific draining basins. The Atlantic region is approximately 2.3 times larger than the Pacific and drains $70 \%$ of the territory. The most abundant rivers, as well as those with the largest watersheds, are also found within the Atlantic region (Leonard, 1987).

\section{The water issue}

According to the World Meteorological Organization, all the countries of the Central American isthmus with the exception of El Salvador are classified as wealthy in terms of water resources. In other words, they use less than $10 \%$ of their available water resources (SG-SICA, 2001). The average per capita availability of water in the region is more than $28,000 \mathrm{~m}^{3} / \mathrm{year}$, with the maximum value in Belize of around 58,500 $\mathrm{m}^{3} /$ year and the minimum in El Salvador of less than 2,800 $\mathrm{m}^{3}$ /year (CEPAL, 2003).

Considering the overall abundance of water, it would seem that the Central American region would have no problems in meeting demands for its various water uses, but this is not the reality. Three main factors are responsible for this apparent contradiction: seasonality in supplies, quality and population distribution. In terms of seasonality, rainfall in Central America, like most other regions, is not distributed evenly throughout the year. There are heavy rains and river flows in some months (May to December) and little in others. Further, storage facilities that might mitigate the effects of seasonality are not generally developed.

Even when supplies are high, they are often of low quality with high degrees of turbidity and sedimentation caused by erosion. The main cause of 
the erosion in Central America is generally believed to be deforestation, which is itself a product of agricultural expansion. Water quality has also been heavily degraded in the areas surrounding many cities.

Adding to the supply problems from both these hydrologic factors is the location of human activity in the region. Interestingly, the population distribution in Central America is inversely related to the total potential availability of water. Almost symmetrically, $30 \%$ of the water is found in watersheds flowing towards the Pacific and $70 \%$ towards the Atlantic, whereas $30 \%$ of the population is located in the Atlantic zone and $70 \%$ in the Pacific. Because of higher population, the Pacific region also has the greatest economic activity. This, coupled with the seasonality and quality problems, has led to a water shortage in many areas despite what appears to be high average availability. Scarcity has now become an issue in places such as the peninsula of Azuero in Panama, the north-west of Costa Rica, Nicaragua's central and Pacific region, the entire country of El Salvador, western Honduras, as well as the high plateaus and Pacific coast of Guatemala.

\section{Water uses and sources}

Overall water extraction in Central America is about 19,000 million cubic metres or less than $3 \%$ of the total water availability (Table 6.1). Per capita extraction is estimated at $656 \mathrm{~m}^{3}$ /year. Costa Rica has the greatest extraction, both in total and per capita, but it still amounts to only $5 \%$ of total available supplies.

Agriculture is the main user of extracted water in the region, with a per capita consumption of approximately $2200 \mathrm{~m}^{3} /$ year (excluding Belize and El Salvador for which data are not available). Most of agriculture uses surface water as supplemental irrigation during the dry season (Losilla et al., 2001). Agricultural use is followed in importance by domestic consumption and industrial demand. By the statistics in Table 6.1, agriculture accounts for more than $80 \%$ of use. However, figures for the industrial sector are likely underestimates. The primary reason for the underestimate is poor information on groundwater abstraction. The main source of water for industry is groundwater, and there is no system for concessions or inventories that would make it possible to measure, or control, consumption levels. Also omitted from the estimates are environmental water use and the generally non-consumptive use of water for tourism and hydroelectric power.

In addition to its use in industry, groundwater from springs and wells also accounts for an estimated $50-95 \%$ of the water being used in the public (domestic) supply system (Losilla et al., 2001). One reason for the high utilization of groundwater is that the majority of surface supplies are of insufficient quality due to poor land-use practices and poorly planned urban expansion. Groundwater is particularly important for domestic supply in Belize, where it accounts for $95 \%$ use. Groundwater is similarly important for domestic supply in Costa Rica. In fact, groundwater accounts for almost $88 \%$ of Costa Rica's extraction to satisfy all consumptive demands, i.e. all uses with the exception of hydroelectric generation. 
Table 6.1. Central America: water resources and use.

\begin{tabular}{|c|c|c|c|c|c|c|c|c|c|}
\hline & \multirow{2}{*}{$\begin{array}{l}\text { Rainfalla } \\
\text { (m/year) }\end{array}$} & \multirow{2}{*}{$\begin{array}{l}\text { Total water } \\
\text { resources } \\
\text { (million } \\
\mathrm{m}^{3} / \text { year) }\end{array}$} & \multirow{2}{*}{$\begin{array}{l}\text { Per capita } \\
\text { water } \\
\text { resources } \\
{\text { ( } \mathrm{m}^{3} / \text { year) }}^{\text {s }}\end{array}$} & \multirow{2}{*}{$\begin{array}{l}\text { Total } \\
\text { extraction } \\
\text { (million } \\
\mathrm{m}^{3} / \text { year) }\end{array}$} & \multirow{2}{*}{$\begin{array}{c}\text { Per capita } \\
\text { extraction } \\
\left(\mathrm{m}^{3} / \text { year }\right)\end{array}$} & \multicolumn{3}{|c|}{ Per capita extraction ${ }^{c}\left(\mathrm{~m}^{3} /\right.$ year $)$} & \multirow{2}{*}{$\begin{array}{l}\text { Extraction as } \\
\text { a percentage } \\
\text { of resources }\end{array}$} \\
\hline & & & & & & Domestic & Industry & Agriculture & \\
\hline Belize & $1.5-4.6$ & 15,258 & 58,458 & 101 & 389 & - & - & - & 0.7 \\
\hline Guatemala & 2.2 & 111,855 & 8,857 & 2,702 & 214 & 33 & 36 & 145 & 2.4 \\
\hline Honduras & 1.9 & 90,031 & 13,776 & 1,745 & 267 & 37 & 10 & 220 & 1.9 \\
\hline El Salvador & 1.2 & 18,616 & 2,755 & 797 & 118 & - & - & - & 4.3 \\
\hline Nicaragua & $1.0-4.0$ & 195,238 & 34,672 & 1,759 & 312.3 & 59 & 2.4 & 250.9 & 0.9 \\
\hline Costa Rica & 3.3 & 118,720 & 27,967 & 6,032 & 1421 & 158 & 76.4 & 1,187 & 5.1 \\
\hline Panama & 3.0 & 156,259 & 49,262 & 59,316 & 1870 & 1453 & 14 & 403 & 38.0 \\
\hline Central America & & 705,976 & 27,965 & 19,069 & 656 & - & - & - & 2.7 \\
\hline
\end{tabular}

aInformation taken from each country report.

bWorld Bank (2005).

${ }^{\mathrm{C}} \mathrm{CRRH}$-SICA, GWP-CATAC-UICN (2002). 
For Costa Rica, projections for water demand for all uses by 2020 are estimated to reach $39 \mathrm{~km}^{3}$, equivalent to $35 \%$ of the total water resources in the country. Even so, urban development continues to increase the pressure on water resources, regardless of the policies for conservation and protection adopted by the country. In some regions, signs of conflict and competition for water use are already being observed. In conclusion, the use of water, groundwater in particular, is becoming increasingly more complex every day.

\section{Groundwater resources in Central America}

Information on the location and availability of groundwater resources in the seven countries of Central American is both limited and variable. For example, while understanding is somewhat greater in Nicaragua and Costa Rica, in Belize existing aquifers and their annual discharge have hardly been studied. Still general information is available for most countries and is summarized in Table 6.2 and general patterns are discussed here.

In general terms, the higher parts of the watersheds in Central America are underlain by volcanic aquifers. In the lower river basins and inland valleys, aquifers of recent alluviums predominate, whereas in the middle parts of the river basins the aquifers are a mixture of volcanic materials, colluvial alluvials and, of lesser importance, aquifers of sedimentary rocks (Losilla et al., 2001). Although important alluvial aquifers do exist throughout the region and some important sedimentary rock aquifers are found in Honduras, Guatemala and Belize, of particular importance to groundwater use are the highly porous soils throughout the Pacific volcanic chain that permit very high levels of rainwater infiltration to recharge the local aquifer systems (GWP, 2005). Their presence has been important historically for attracting settlements and population concentrations in the region's Pacific watersheds where, in most cases, the springs and eventual pumping from local wells have met the demand for water. Volcanic aquifers now provide potable water for most major Central American cities including Guatemala, Tegucigalpa, San Salvador, Managua and San Jose.

Unfortunately, the volcanic aquifers consist mainly of interstratifications of tuffs, gaps and quaternary as well as some tertiary lava, which present high permeability and fissure flows. In many cases, these make the aquifers highly vulnerable to human contamination from the cities they help to support. The heterogeneity of these aquifers, with differential horizontal and vertical flows, also makes them quite complicated to study and therefore to manage.

In general, the recharge of the main aquifers in Central America is accomplished by rainwater infiltration and to a lesser degree by a connection with surface water and excess of irrigation water application.

\section{Threats to groundwater}

The overexploitation of water is most clearly seen where the population is concentrated in metropolitan areas, which increases the demand for extracting 
Table 6.2. Characteristics of the main aquifers in Central America. (From Losilla et al., 2001.)

\begin{tabular}{ll}
\hline Country & Characteristics \\
\hline Belize & No information is available.
\end{tabular}

Belize

Guatemala Four very important aquifers are located in Guatemala: the upper and lower aquifers in the central highlands and in the valley of Guatemala. The upper aquifer in the high plateau is mainly formed by volcanic quaternary rocks, and the lower aquifer basically consists of lutitas, welded dacite and andesite tuffs, and basaltic andesite lava flows from the tertiary era, which has been fragmented locally. Although we have little information about the aquifers in the high plateaus, which have yet to be exploited, it is known that they are not confined, with a depth of $250 \mathrm{~m}$ and a production of $3-70 \mathrm{l} / \mathrm{s}$. Land in the central plateau is now mainly for cultivating coffee and vegetables, as well as for pastures and brushland.

The aquifers in the upper and lower valley of Guatemala are hydrologically connected. The upper aquifer has no quaternary formations, and its depth varies from 5 to more than $50 \mathrm{~m}$; the lower aquifer is of tertiary formation, with a depth of $200-250 \mathrm{~m}$, and extends over $550 \mathrm{~km}^{2}$ with a water flow of up to $300 \mathrm{l} / \mathrm{s}$. The recharge area of these aquifers is in the valley of Guatemala, with the exception of part of Lake Amatitlán, as well as other areas covered by urbanization.

Nicaragua The Managua aquifer is located in the western central area of the country and extends for approximately $600 \mathrm{~km}^{2}$; it has a saturated thickness that ranges from 200 to more than $450 \mathrm{~m}$. There are approximately 160 excavated central wells and a total of 663 perforated wells with different uses, among which are domestic, municipal, industrial, agribusiness and irrigation. The depth of the perforated wells ranges between approximately 42 and $500 \mathrm{~m}$. The average water flow from the wells is $3170 \mathrm{~m}^{3} /$ day, with a production capacity that ranges between 470 and $8500 \mathrm{~m}^{3} /$ day. In 1996, the production of water was $131.4 \times 10 \mathrm{~m}^{3} /$ year. Nearly 1.5 million people were supplied from the groundwater in this aquifer, via the Managua aqueducts. According to a 1993 JICA/INAA study, west of the Managua aquifer there is large-scale irrigation for the main crops of maize, sorghum and beans. Central-pivot irrigation covers an area of approximately $247 \mathrm{ha}$. During 1993, the irrigated area was about 170 ha, and there was a total of $1700 \mathrm{~h}$ of pumping. There is an annual discharge of approximately 1.24 million cubic metres. The quantity of water required is approximately equal to the water consumed; when the planted area is $150 \mathrm{ha}$, consumption is 1275 million $\mathrm{m}^{3}$, which is similar to the amount of water extracted annually.

Honduras In Tegucigalpa, the capital of Honduras, there are more than 500 perforated wells, which yield 1-3l/s; there are zones in the volcanic ash that have low yields, although some have greater yields (2-20l/s).

El Salvador In the department of San Salvador, a region of economic importance to the country, there is a group of aquifers that form a very complex water system due to the emergence of springs and of connections between surface and groundwater flows. To the west of the San Salvador aquifers, water for agricultural activity is extracted from wells located in the Zapotitán Valley, which is dedicated to agriculture. To the east is the San Salvador aquifer, which coincides with the metropolitan area of the capital city, and covers 
Table 6.2. Continued

Country Characteristics

an area of approximately $185 \mathrm{~km}^{2}$, with an annual yield of $42 \times 10^{6} \mathrm{~m}^{3} /$ year $\left(1.35 \mathrm{~m}^{3} / \mathrm{s}\right)$. The rest of the aquifers of this zone are mainly in the coastal plains or along the coastline. In general, they are very limited aquifers because of their proximity to the coast and because of the influence of salt water.

Approximately 227 million cubic metres of groundwater is extracted annually and $80 \%$ of the potable water supply comes from groundwater. The reliable yield of the existing groundwater deposits in the country are estimated at $83 \mathrm{~m}^{3} / \mathrm{s}$.

The largest basins at the highest elevation with potential groundwater, in order of importance, are the Lempa and Jalponga rivers combined, Grande de San Miguel and Paz. However, the potential is not uniformly distributed. The aquifers in El Salvador were formed according to structural zones: the northern Sierras, the central depression, and the mountains and plains of the Pacific coast are formed by impermeable rocks. There are coastal aquifer formations with depths of more than $150 \mathrm{~m}$ and with average water flows of $16 \mathrm{l} / \mathrm{s}$. The Santa Ana aquifer in the western zone has a high potential for exploitation, with a flow of $3.5 \times 10^{6} \mathrm{~m}^{3} / \mathrm{year} / \mathrm{km}$.

Costa Rica

The characteristics of high permeability in the layers of fragmented and igneous lava, combined with high rainfall, favoured the formation of highly potential aquifers in the central and northern part of Costa Rica's Central Valley, where more than half of the population lives. These aquifers are called the Upper and Lower Colima and are separated by a low permeability layer that acts as an aquitard, which allows the descending and ascending vertical transfer of water.

It has been estimated that the Lower Colima extends for approximately $230 \mathrm{~km}^{2}$ and that the Upper Colima spreads over approximately $170 \mathrm{~km}^{2}$. The maximum thickness is about $300 \mathrm{~m}$. The outcropping of this lava is limited to the river canyons in the lower part of the valley. According to SENARA/BGS (1989), the Upper Colima aquifer recharges from the Barva aquifer through the tuffs of the unit known as the Tiribí formation and from the La Libertad aquifer by vertical percolation. The Upper Colima also receives a large part of its recharge from rain infiltration in those areas where there are no overlying layers. The Lower Colima is recharged from the Upper Colima by vertical percolation through the tuffs and ignimbrites of Puente de Mulas, or from the surface where the Upper Colima is absent. The average recharge in the aquifer system has been calculated at $8200 \mathrm{l} / \mathrm{s}$ (TAHAL, 1990).

The flows extracted from the wells that collect from both aquifers are 50-120 l/s (SENARA/BGS, 1989). The depth of the water table level varies, depending on the surface topographical irregularities; but, in general terms, it ranges between 50 and $100 \mathrm{~m}$. The direction of the underground flow is from north-east to south-west in both aquifers.

Panama The hydrological characteristics of the geological formations in Panama are little known because of the lack of systematic studies. It is known that production from wells is generally acceptable. The majority of the aquifers that are exploited are of a type of fissure flow in volcanic rocks and of sedimentary and fissured conglomerates. The depth of the majority of the wells ranges from 20 to $110 \mathrm{~m}$ and production is $2-15 \mathrm{l} / \mathrm{s}$. 
groundwater at rates that exceed the capacity of the natural cycle to recharge the aquifers. Aquifers under virtually all of the metropolitan areas in Central America show signs of overexploitation. At the same time, urban expansion is covering the surfaces from which the aquifers would naturally be recharged. So while demands on the aquifers rise, their supply falls. The case of the aquifers in Guatemala, Managua in Nicaragua, and San Pedro Sula in Honduras exemplify this problem.

In Guatemala, a continuous decline of groundwater has been identified in the southern basin of the valley of Guatemala, as well as in the metropolitan area. In the case of El Salvador, the urbanized surface of the metropolitan area has increased almost exponentially, from $6.8 \mathrm{~km}^{2}$ in 1935 to the current $91.5 \mathrm{~km}^{2}$, and this has mainly taken place in the largest aquifer recharge areas. Because of this, the areas with the highest rate of infiltration have been reduced, whereas the areas with an infiltration rate of 0.05 (the rate assigned to areas of low impermeability) have increased by the same proportion. The same thing has happened in San Pedro Sula, Honduras.

The demographic projections of the United Nations Development Program (UNDP) indicate that by 2010 more than $60 \%$ of the population in all countries in the region with the exception of Guatemala will be concentrated in urban centres. All of these, with the exception of Honduras, are located within the Pacific region.

As mentioned above, groundwater in Central America is extremely vulnerable to pollution because the aquifers are relatively superficial and are covered by fractured or permeable materials. In areas of high precipitation, the infiltration of polluting agents potentially toxic to human health can be from $30 \%$ to $50 \%$ (Reynolds, 1992). The main sources of groundwater pollution are agricultural and industrial activities, along with domestic runoff.

A study conducted by the Food and Agricultural Organization (FAO) of the problems of pollution in 16 Latin American countries determined that in urban areas the main sources of polluting agents from agricultural activities are fertilizers, pesticides and food-processing industries, whereas in rural areas the contaminants are associated with pesticides and fertilizers of chemical origin. Intensive agriculture is one of the main sources of income in Central America. Great volumes of water are used as farmers seek the highest possible levels of performance, thus forcing irrational use in the dry season and uncontrolled use of pesticides and herbicides, which in turn lead to situations of risk.

A total of 10.1 million tonnes of chemical fertilizers were used in the region from 1980 to 2000. Interestingly, as shown in Fig. 6.2, the use of chemical fertilizers in Central America has revealed quite irregular tendencies, with use increasing by $20 \%$ in some years (1983 and 1997) and falling markedly in others (1982 and 1989). This use of agrochemicals and fertilizers in the region has contaminated some important aquifers.

Pollution caused from mercury and phosphates has been observed in Guatemala. In El Salvador, rivers and streams in the principal agricultural areas are highly polluted by pesticides, particularly by DDT in cotton cultivations in the south-eastern coastal plains. Concentrations of $3.15 \mathrm{mg}$ of DDT per litre of water have been discovered in the Río Grande de San Miguel, which is triple the 


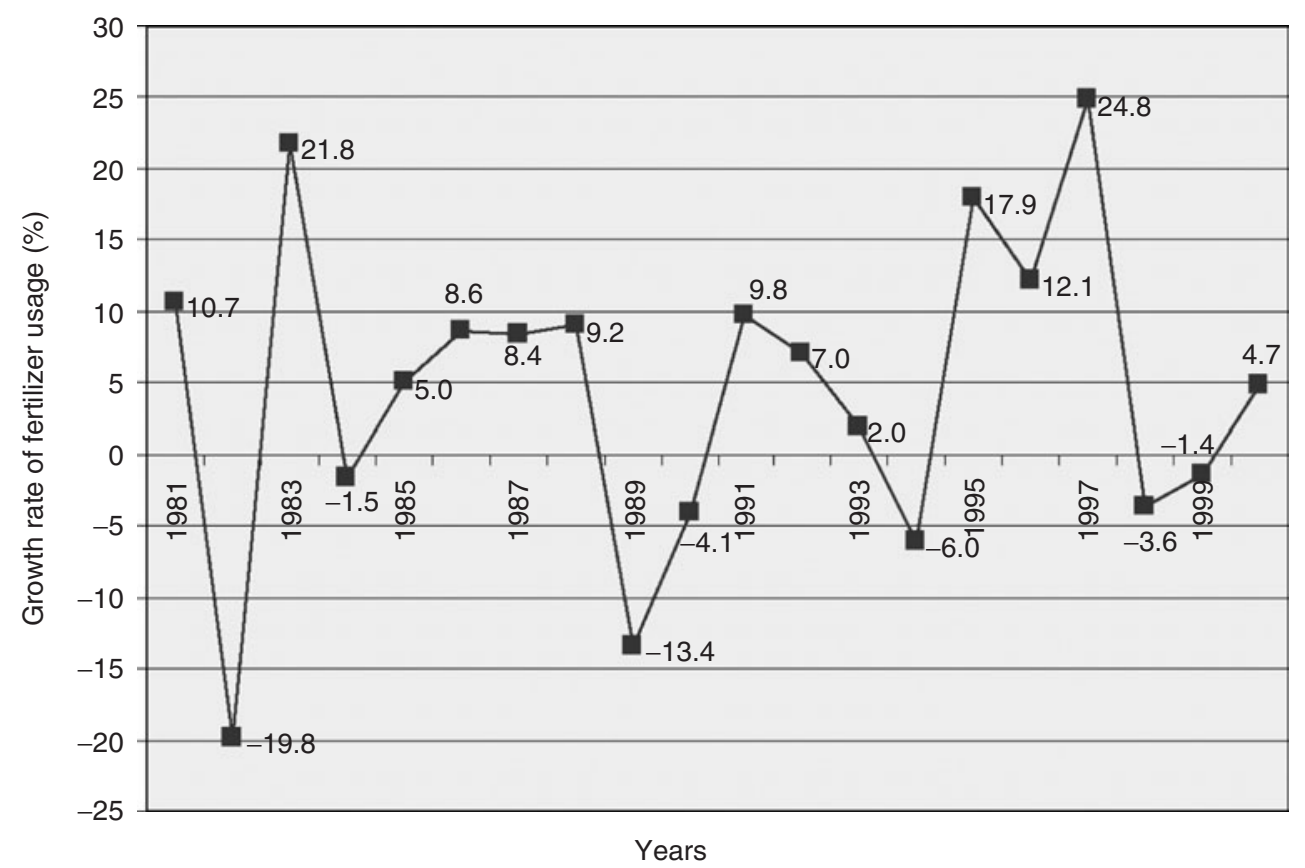

Fig. 6.2. Growth rate in the amount of chemical fertilizers used in agricultural activities for the period 1980-2000 in Central America.

lethal limit for fish. Toxaphene (non-biodegradable) pollution has been detected in Nicaragua in concentrations that exceed acceptable standards (Silvel et al., 1997; CIEUA, 1998; Aquastat, 2001). In the case of Nicaragua, this problem is of great concern for the western aquifers (León-Chinandega) and the valley of Sébaco, as is the case in Guatemala for the sugarcane and banana plantations in the Pacific and Caribbean coastal regions (Choza, 2002).

Pesticides such as toxaphene were detected in the Siguatepeque aquifer in Honduras and in the León-Chinandega aquifer in Nicaragua, although in smaller concentrations to those permitted by the World Health Organization (WHO). There was intensive cultivation of cotton on top of these aquifers during the 1960s and 1970s. Likewise, insecticides such as clorado, carbofuran and 2,4-D, which are used for agricultural production, have been detected in rural areas of Honduras, although in concentrations that are lower than those permitted by the WHO.

In La Libertad spring in Costa Rica, on three occasions, concentrations of nitrate that exceed the norm of $45 \mathrm{mg} / \mathrm{NO}_{3}^{-}$have been detected, while a slight increase in the nitrate concentration of $2 \mathrm{mg} / \mathrm{l}$ was observed between 1986 and 1997. This indicates that in less than one decade the maximum permissible concentration would have been reached.

Nitrates have been detected in El Salvador, Nicaragua and Costa Rica. In the north-eastern sector of Managua's aquifer, high concentrations of almost $45 \mathrm{mg} / \mathrm{l} \mathrm{NO}-\mathrm{N}_{3}^{-}$were reported, probably because of the use of nitrogenous fertilizers (Hetch, 1989). 
The non-agricultural causes of contamination in urban areas are domestic runoff and industrial waste. For example, there is substantial data on faecal pollution in the aquifers located in urban zones. According to monitoring by the National Administration of Aqueducts and Sewers (ANDA) of the public wells in El Salvador, of 183 samples that were taken during a 10-year period from 31 wells, it was found that $10 \%$ of the wells showed high rates of coliform, which exceeded the permitted level. Likewise, there are zones in the metropolitan area where the percentage of wells contaminated by coliforms in excess of permitted levels is more than $50 \%$; this is where there has been indiscriminate land use for both residential and industrial purposes.

\section{Agriculture and Water Use in Central America}

Although Central America has traditionally been an agricultural region, in the last 20 years it has witnessed a process of diversification and increased wealth generation from other sectors such as industry, high technology and services. In spite of this, agriculture continues to generate an important part (14.8\%) of the total gross domestic product (GDP) and has continued to expand, at $2.3 \%$ between 1995 and 2002 (CEPAL, 2003). Nicaragua is the country most dependent on agriculture. There the sector contributes one-third of total GDP, with contributions coming particularly from the export of coffee ( $\$ 98.3$ million) and sugar (\$33.4 million).

In Guatemala, where $75 \%$ of families live in extreme poverty, agriculture is the most productive sector and provides $25 \%$ of the GDP. It is also the most important activity for the people who live in the high central plateau, and creates jobs and income for $68 \%$ of the population. The export products are principally coffee and cotton, while maize, beans, wheat, vegetables and fruit are produced for domestic consumption.

Countries such as Costa Rica and Panama have diversified their exports by producing high-tech goods followed by seafood products. This has reduced the agricultural sector's proportion of the GDP from $11 \%$ to $7 \%$ in both countries, although they still export products such as bananas, coffee, sugar, pineapple and melon. However, this relatively low contribution of agriculture remains high, even in the case of Panama, when compared with that of developed countries. We must remember that the region's economies are still highly dependent on agriculture. This discussion and the figures shown in Table 6.1 highlight that even though agriculture may be declining as percentage of output, it is still important for the overall economy and for water use in particular.

\section{Irrigation by country}

\section{Belize $^{1}$}

Because of land quality, only $6.1 \%$ of Belize's area is dedicated to agriculture. Still that area contributes $19 \%$ of GDP. Of total agricultural area, only about $5 \%$ or 3,500 ha is irrigated, supporting about 177 producers, as shown in Table 6.3. 
Table 6.3. Belize: irrigated area, irrigation methods, supply sources and main crops by district, 2005. (From Ministry of Agriculture of Belize, 2005.)

\begin{tabular}{|c|c|c|c|c|c|c|c|c|}
\hline District & Crop & Location & $\begin{array}{l}\text { Estimated } \\
\text { Number of } \\
\text { farmers }\end{array}$ & Area (ha) & $\begin{array}{l}\text { Method of } \\
\text { irrigation }\end{array}$ & $\begin{array}{l}\text { Water } \\
\text { source }\end{array}$ & $\begin{array}{l}\text { Average } \\
\text { yield } \\
\text { (gpm) }\end{array}$ & $\begin{array}{l}\text { Quality of } \\
\text { water }\end{array}$ \\
\hline \multirow[t]{3}{*}{ Corozal } & $\begin{array}{l}\text { Papaya Tainong/ } \\
\text { Solo }\end{array}$ & Fruita Bomba & 1 & 623.8 & Drip & Well & 120 & Hard water \\
\hline & Papaya Tainong & Little Belize & 30 & 81 & Drip & Well & 100 & Hard water \\
\hline & $\begin{array}{l}\text { Vegetables (onions, } \\
\text { cabbage, hot } \\
\text { pepper) }\end{array}$ & Small farms & 70 & 31.6 & Drip & Well & 100 & Hard water \\
\hline Subtotal & & & & 736.4 & & & & \\
\hline \multirow[t]{4}{*}{ Orange Walk } & Rice & Blue Creek & 3 & 1417.5 & Basin/flood & River & Unlimited & Fresh \\
\hline & Papaya Tainong & Indian Creek & 1 & 2 & Drip & Well & $50-100$ & Fresh \\
\hline & Hot pepper & San Carlos & 4 & 3.2 & Drip & Well & $50-100$ & Fresh \\
\hline & $\begin{array}{l}\text { Vegetables } \\
\text { (hot pepper, } \\
\text { cabbage, sweet } \\
\text { pepper, tomatoes, } \\
\text { onions, lettuce, } \\
\text { sweet corn, } \\
\text { broccoli, carrots, } \\
\text { potatoes) }\end{array}$ & Small farms & 28 & 20.3 & Drip & Well & $50-100$ & $\begin{array}{l}\text { Fresh but saline } \\
\text { Along coastal } \\
\text { areas }\end{array}$ \\
\hline Subtotal & & & & 1443 & & & & \\
\hline Belize & Rice & Singh Tut & 1 & 81 & Basin/flood & River & Unlimited & Fresh \\
\hline District & Vegetables & Small farms & 15 & 14.2 & Drip & Well & $50-100$ & $\begin{array}{l}\text { Fresh but } \\
\text { saline along } \\
\text { coastal areas }\end{array}$ \\
\hline Subtotal & & & & 95.2 & & & & Continued \\
\hline
\end{tabular}


Table 6.3. Continued

\begin{tabular}{|c|c|c|c|c|c|c|c|c|}
\hline District & Crop & Location & $\begin{array}{l}\text { Estimated } \\
\text { Number of } \\
\text { farmers }\end{array}$ & Area (ha) & $\begin{array}{l}\text { Method of } \\
\text { irrigation }\end{array}$ & $\begin{array}{l}\text { Water } \\
\text { source }\end{array}$ & $\begin{array}{l}\text { Average } \\
\text { yield } \\
\text { (gpm) }\end{array}$ & $\begin{array}{l}\text { Quality of } \\
\text { water }\end{array}$ \\
\hline \multirow[t]{2}{*}{ Cayo } & Papaya & $D \& L$ & 1 & 14.2 & Drip & Well & 120 & Fresh \\
\hline & $\begin{array}{l}\text { Vegetable (cabbage, } \\
\text { carrots, lettuce, } \\
\text { cucumbers) }\end{array}$ & Small farms & 5 & 2.8 & Drip & $\begin{array}{l}\text { River/ } \\
\text { stream }\end{array}$ & $\begin{array}{l}\text { Unlimited } \\
\text { for rivers } \\
\text { but streams, } \\
\text { ponds can } \\
\text { run dry in } \\
\text { summer }\end{array}$ & Fresh \\
\hline Subtotal & & & & 17.0 & & & & \\
\hline Stann & $\begin{array}{l}\text { Bannanas for } \\
\text { export }\end{array}$ & Big Creek & 6 & 1215 & $\begin{array}{l}\text { Sprinkler/ } \\
\text { under } \\
\text { canopy }\end{array}$ & River & & Fresh \\
\hline Creek & $\begin{array}{l}\text { Vegetables } \\
\text { (hot pepper) }\end{array}$ & Small farm & 2 & 2 & Drip & Well & 100 & Fresh \\
\hline Subtotal & & & & 1217 & & & & \\
\hline \multirow[t]{2}{*}{ Toledo } & Rice & Farms & 2 & 36.5 & Basin/flood & River & Unlimited & Fresh \\
\hline & Rice & Small farm & 8 & 3.2 & Basin/flood & River & Unlimited & Fresh \\
\hline Subtotal & & & & 39.7 & & & & \\
\hline Total & & & 177 & 3548.3 & & & & \\
\hline
\end{tabular}


As much as $66 \%$ of the current irrigation is located in the mid-southern region and more than $94 \%$ is delivered by systems of low water use efficiency, sprinklers and surface water. Experiences have so far indicated that irrigation development has been successful only in monocrops of high-intensity production such as bananas, papayas and double cropping of rice. It played no role in the milpa system. The low input and low productivity levels that characterize other crops could not justify this additional input.

Contrary to the other countries in Central America, all of the irrigation systems in Belize are private and were developed with private funds or loans from international cooperation organizations such as the European Union (EU). State support through the Ministry of Agriculture is reduced to technical assistance for small producers and to facilitating the financing requests of large producers. Because these systems are private, there is no tariff system; the costs of development and maintenance are totally paid for by the producers.

There is a deficit of crop water during 4-9 months of the year, and the potential for irrigation increases from south to north. For the purpose of considering resources for irrigation, the country can be subdivided into three main areas as summarized in Table 6.3: (i) a southern high rainfall area (Stann Creek and Toledo); (ii) an intermediate rainfall area in the rolling lands of the central foothills (Cayo and the southern area of Belize); and (iii) a much drier northern plateau with diverse land systems (Corozal and the northern area of Belize).

The south has an abundant supply of good-quality surface water for use in the dry season and could support irrigation systems with low water use efficiencies, such as flood irrigation and, to a lesser degree, sprinklers or drip. Soil macro-structure poses a constraint to water use as the experiences of the largest irrigation project -1215 ha of irrigated bananas - have illustrated. Southern communities in Toledo, where principally rice is grown, do not experience water problems in the dry season.

The central foothills, home to many small farming communities, face a water shortage during the dry season. Because the shallow and often stony soils present no real problems for soil water dynamics, the development of water storage facilities is most relevant to this area. However, the area is most conducive to irrigation systems with high water use efficiencies for the production of rice, vegetables and papaya. Water quality is good throughout the dry season although the supply is low.

The northern plateau, with its diverse land systems, is characterized by lagoons, creeks, swamps, subsurface storage in limestone aquifers and slow and sluggish flowing rivers. Availability of water for dry season use is good, but access to surface and groundwater sources poses problems for domestic and agricultural use in small farming communities. The water resources can support irrigation systems of low water use efficiency on the river banks, but is conducive to the more efficient water use system in other areas. Except for its high natural variability and shallow nature, the soil structure offers no constraints to soil water dynamics.

\section{Guatemala ${ }^{2}$}

As can be seen in Table 6.4, the total irrigated area in Guatemala is estimated at just more than 140,000 ha, of which surface water is used to irrigate $78.2 \%$ and 
Table 6.4. Guatemala: area under irrigation by water source. (From Support Program for the Reconversion of Food and Agriculture Production (PARPA), based on PLAMAR-MAGA data, 2003-2004.)

\begin{tabular}{lccr}
\hline & \multicolumn{2}{c}{ Irrigated area (ha) } & Total irrigated \\
\cline { 2 - 3 } Department & Groundwater & Surface water & area \\
\hline Alta Verapaz & 252 & 479 & 731 \\
Baja Verapaz & 76.8 & $2,073.5$ & $2,150.3$ \\
Chimaltenango & 481.7 & 211.5 & 693.2 \\
Chiquimula & 644.2 & $1,498.6$ & $2,142.9$ \\
El Progreso & 325.7 & $1,722.6$ & $2,048.3$ \\
Escuintla & $23,456.9$ & $28,205.4$ & $51,662.3$ \\
Guatemala & 170.5 & $1,036.5$ & 1,207 \\
Huehuetenango & - & $1,035.8$ & $1,035.8$ \\
Izabal & 339.5 & $10,037.1$ & $10,376.6$ \\
Jalapa & $1,015.3$ & 964.5 & $1,979.8$ \\
Jutiapa & 700.5 & $2,067.3$ & $2,767.8$ \\
Petén & 353.1 & 258.3 & 611.4 \\
Quetzaltenango & 209.2 & 791.5 & $1,000.7$ \\
Quiche & - & 413.5 & 413.5 \\
Retalhuleu & 864.5 & 7,113 & $7,977.5$ \\
Sacatepéquez & 125.1 & 1,663 & $1,788.1$ \\
San Marcos & 530.4 & $5,326.1$ & $5,856.5$ \\
Santa Rosa & 703 & $3,099.5$ & $3,802.5$ \\
Sololá & 0.7 & 308.2 & 308.9 \\
Suchitepéquez & 428.7 & $31,508.8$ & $31,937.5$ \\
Totonicapán & 43 & 61.1 & 104.1 \\
Zacapa & 290.1 & $11,612.8$ & $11,902.9$ \\
Total & 31,011 & $111,487.8$ & $142,498.9$ \\
\hline
\end{tabular}

groundwater, $21.8 \%$. The departments with the largest areas under irrigation are Escuintla (51,662.3 ha), Suchitepéquez (31,937.5 ha), Zacapa (11,902.9 ha) and Izabal (10,376.6 ha). This sector utilizes approximately $41 \mathrm{~m}^{3} / \mathrm{s}$, equivalent to $1.3 \mathrm{~km}^{3} /$ year.

The process of constructing community irrigation systems in Guatemala began in the early 20th century. Since the 1960s the government of Guatemala has supported the construction of public irrigation units that cover 15,229 ha and directly benefit 4402 families; another 64,000 ha is under private irrigation systems. This is a small percentage compared to the 2.5 million hectares that could potentially be irrigated. The government-constructed systems generally use surface water, whereas the majority of the private systems use pressurized systems (sprinklers or drip). The efficiency of the irrigation systems has been questioned; however, water utilized for irrigation accounts for scarcely $1.3 \%$ of the surface water sources in the country.

In 1982, the first attempts were made to transfer irrigation units to users. The process was intensified in 1988, and in the 1990s the transfer of the administration, operation and maintenance of the irrigation units took place. Currently, 
only five of these units remain to be transferred to the users: Llano de Morales in Sanarate municipality, El Progreso department; and Las Canoas and Rincón de la Pala in the department of Guatemala.

The state began a parallel process to reduce its attention to irrigation management so as to reduce the budget and personnel assigned. However, it was not successful in obtaining the conscientious and voluntary participation of the users. The result has been an accelerated deterioration of the infrastructure. Additional measures have been taken to solve this problem, in particular the 'remodelling' of irrigation infrastructure supported by the state, but problems remain.

In order to provide a short-term solution to the needs of the producers, 940 small irrigation systems were built between 1990 and 2004, at a cost of \$20.3 million. These cover an area of 9049.5 ha and are administered by the users. In the areas where the majority of the projects are located, groundwater is used with the most efficient techniques such as drip, sprinkler or mixed irrigation, for example, in the production of sugarcane and plantains in Escuintla and Suchitepéquez, and of cantaloupe, mango and citrus fruit in Zacapa.

\section{El Salvador ${ }^{3}$}

In El Salvador, $77.4 \%$ of the land is dedicated to agriculture though only $4.4 \%$ $(35,000 \mathrm{ha})$ is irrigated, mostly for crops such as pasture, maize, sugarcane, rice and vegetables. However, nearly $70 \%$ of the total water consumption in the country is for irrigation, in strong competition with other uses.

It is estimated that 7715 families benefit from the irrigation systems in the country, as can be seen in Table 6.5. However, in 2005, the Ministry of Agriculture and Livestock began taking a census to update the registry of irrigation users throughout the country, which would provide information about the exact number of hectares under irrigation, the techniques and the supply sources (surface or groundwater), as well as the number of families that benefit. The partial results indicate that in departments such as Sonsonate and Ahuachapán there was a $128 \%$ increase in the number of hectares irrigated and a $172 \%$ increase in the number of producers utilizing irrigation compared with the previous registry.

Table 6.5. El Salvador: land irrigated with groundwater and the number of beneficiaries by department. (From Department of Irrigation and Drainage, Ministry of Agriculture and Livestock, El Salvador, 2005.)

\begin{tabular}{lcc}
\hline Department & $\begin{array}{c}\text { Area irrigated with } \\
\text { groundwater (ha) }\end{array}$ & \begin{tabular}{c} 
Number of beneficiaries \\
\hline Ahuachapán
\end{tabular} \\
Sonsonete & 1014 & 2535 \\
La Paz & 31.3 & 78 \\
Usulatán & 7 & 18 \\
La Unión & 1.5 & 4 \\
La Libertad & 32.5 & 80 \\
Total & 2000 & 5000 \\
\hline
\end{tabular}


More than $90 \%$ of the water utilized for irrigation comes from surface sources and gravity irrigation is used by more than $90 \%$ of the users, according to the results obtained in Sonsonate and Ahuachapán; techniques such as sprinklers, drip or mixed are used by few producers. This suggests high levels of inefficient water use despite the fact that El Salvador has the greatest water stress in the region.

Irrigation systems are organized in 43 irrigation associations that cover $50 \%$ of the irrigated area; 39 correspond to private systems and 4 to public systems (irrigation districts). Only $32 \%$ of the irrigated land in private systems is in associations, whereas $100 \%$ of public systems are in associations. Of all irrigation associations $51 \%$ are in Sonsonate.

The irrigation and drainage law authorizes the formation of federations. To date, the Federation of Irrigator Associations of El Salvador (FEDARES) and the Federation of Irrigators in the Sensunapán River basin have been formed. The first group brings together the associations of the irrigation and drainage districts of the southern Atiocoyo sector (ARAS), northern Atiocoyo sector (ARAN) and Zapotitán (AREZA); the second group is made up of seven private associations.

Investment in the public irrigation districts is financed by the state, to a maximum of $\$ 2,225,000$. However, the users of the irrigation system are responsible for recuperating $50 \%$ of the investment. Each district establishes a tariff that will make it possible to recuperate the amount agreed upon in the time period that is negotiated between the beneficiaries and the Ministry of Agriculture and Livestock. In the same manner, the state finances the private irrigation associations; however, these groups must contribute $20 \%$ of the total investment, which cannot exceed \$2000/ha.

In addition, by executive agreement, each district charges a minimum rate of $\$ 5.24 /$ ha/year to operate and maintain the system. However, this amount does not cover the real needs of the irrigation systems, so the users have established voluntary tariffs of about $\$ 40 /$ ha/year, which permits them to keep the systems operating. The private systems establish tariffs through a negotiation process among the members.

\section{Honduras ${ }^{4}$}

Agriculture is the economic base of Honduras. As much as $82 \%$ of the water exploited (national water balance) is directed to agricultural activities, supplying water to a total of 86,631 ha as shown in Table 6.6. Of this total, $92.3 \%$ is supplied by surface water and $7.7 \%$ is extracted from groundwater through wells. The majority of the irrigation systems are located in the departments of Yoro $(30.5 \%)$, Choluteca $(21.2 \%)$ and Cortés $(20.8 \%)$, where, unlike in the rest of the region, mainly sprinkler or drip irrigation is used to cultivate bananas, cantaloupe and sugarcane.

Because of the continuous increase in water utilization, a 25-year master plan for irrigation and drainage is being promoted. Feasibility studies already exist for incorporating 14 projects that include 25,763 ha of irrigated agriculture, in accordance with the need to increase agricultural production for domestic consumption and for exportation. These projects, with an investment 
Table 6.6. Honduras: irrigated area by source and by department. (From the authors, based on information provided by the Secretariat of Agriculture and Livestock (SAG), General Department of Irrigation and Drainage, 2005.)

\begin{tabular}{lcccc}
\hline & \multicolumn{2}{c}{ Water source } & & \\
\cline { 2 - 3 } Department & Surface & Groundwater & Total & Percentage \\
\hline Comayagua-La Paz & $6,684.2$ & 995.9 & $7,680.1$ & 9.4 \\
Valle & 173.3 & 69.2 & 242.5 & 0.3 \\
El Paraíso & $1,407.1$ & 19.2 & $1,426.2$ & 1.7 \\
Choluteca & $14,568.2$ & $2,740.5$ & $17,308.7$ & 21.2 \\
Olancho & 194.8 & 162.3 & 357.2 & 0.4 \\
Atlantida & 1,718 & 200 & 1,918 & 2.3 \\
Colon & $2,613.5$ & - & $2,613.5$ & 3.2 \\
Yoro & $23,866.4$ & $1,018.9$ & $24,885.3$ & 30.5 \\
Cortes & $15,920.1$ & $1,058.3$ & $16,978.4$ & 20.8 \\
Copan & $5,099.8$ & - & $5,099.8$ & 6.2 \\
Santa Barbara & $1,286.9$ & - & $1,286.9$ & 1.6 \\
Intibuca & 209.4 & - & 209.4 & 0.3 \\
Fco. Morazan & $1,334.6$ & - & $1,334.6$ & 1.6 \\
La Paz & 235.7 & - & 235.7 & 0.3 \\
Lempira & 54.8 & - & 54.8 & 0.1 \\
Total & $75,366.6$ & $6,264.3$ & $81,630.9$ & 100 \\
\hline Note: The & & & & \\
\hline
\end{tabular}

Note: The classification of surface and groundwater is the responsibility of the authors and not of the source.

of more than $\$ 143$ million, are intended to benefit 8224 families mainly for the cultivation of vegetables, grains and citrus fruits.

Through implementation of this plan, the government intends to promote and stimulate the private sector to develop secondary and tertiary productive infrastructure in large and small irrigation projects, by giving long-term credit incentives, effective technical assistance and investment guarantees. In addition, it contemplates supporting micro-irrigation and drinking water projects using the modality of co-participation between the community and the government, which would be administered by the users.

\section{Nicaragua 5}

Irrigated agriculture in Nicaragua began in the 1950s and by the 1970s covered more than 70,000 ha. The best soils of the Pacific zone are used and groundwater is the main source of irrigation water. In the 1980s, a contingency plan was implemented for basic grains, using sprinkler systems with an automatic central pivot which have been nearly abandoned. The systems deteriorated mainly because of lack of maintenance, high cost of equipment and lack of technical assistance for operating the systems.

Given that $62.3 \%$ of the land in Nicaragua is dedicated to agriculture and that the potential irrigable area is estimated at 700,000 ha, the government, through the Ministry of Agriculture, created the Western Irrigation Program in 1998 as a mechanism of economic transformation and modernization of agriculture. This 
was accomplished by constructing new irrigation and drainage works, through soft loans from private banks and the Rural Credit Fund, with interest rates of 10-11.5\%. The programme began in the departments of Chinandega and León and later were expanded throughout the rest of the country.

A \$20.2 million loan from the government of the Republic of China was obtained to carry out the Western Irrigation Program. The majority of the funds were used by the Ministry of Agriculture for reconstruction and reposition of irrigation equipment; some were used for preliminary investment and technical assistance, and the remaining were put into investigative studies of surface and groundwaters.

Table 6.7 gives a summary of the funds spent from 1998 to 2005 by each department. The total number of projects constructed includes about 294 beneficiaries and a total investment of $\$ 6.8$ million. The largest number of beneficiaries is concentrated in Matagalpa and León; however, the highest investment is concentrated in Chinandega.

Currently, the irrigation system covers only $4 \%$ of the potential area, or about 30,000 ha. However, even though this represents a small area, there have been conflicts about water use, above all in the central region where the flow of surface water is insufficient to cover the demands of the region and groundwater resources are very limited. The Las Canoas dam is one example. This was constructed by the Victoria de Julio Sugar Refinery to irrigate sugarcane and is causing water use conflicts between water users in the upper and middle basin of the Malacatoya River.

\section{Costa Rica ${ }^{6}$}

The National Irrigation and Drainage Service (SENARA) was created by Law 6877 on 18 July 1983. SENARA is given the authority and direct responsibility for developing the infrastructure, administration and operation of the system,

Table 6.7. Nicaragua: number of beneficiaries and investment by department by irrigation project between 1998 and 2005. (From Ministry of Agriculture and Forestry (MAG-FOR), Nicaragua, 2005.)

\begin{tabular}{lcr}
\hline Department & Number of beneficiaries & Amount (\$) \\
\hline León & 44 & $1,551,726.9$ \\
Chinandega & 18 & $1,959,918.9$ \\
Matagalpa & 62 & $1,169,695.6$ \\
Carazo & 3 & $134,428.9$ \\
Estelí & 39 & $286,423.9$ \\
Chontales & 2 & $56,493.2$ \\
Rivas & 25 & $392,749.3$ \\
Boaco & 3 & $70,491.8$ \\
Managua & 34 & $442,391.2$ \\
Madriz & 52 & $420,983.6$ \\
Granada & 9 & $306,486.9$ \\
Jinotega & 1 & $25,234.6$ \\
Masaya & 2 & $19,882.5$ \\
Total & 294 & $6,836,907.3$ \\
\hline
\end{tabular}


for which it can establish a tariff system that must be approved by the Public Services Regulatory Authority (ARESEP), since irrigation is considered to be a public service.

Currently, SENARA is administering two irrigation systems: ArenalTempisque Irrigation District (DRAT) and Irrigation and Drainage of Small Areas (PARD).

ARENAL-TEMPISQUE IRRIGATION DISTRICT (DRAT) This system is located in Guanacaste province, the driest area of the country (during 5 months a year), and is nearly $100 \%$ supplied by surface water, utilizing water from the artificial Lake Arenal.

In the early 1980s, stage I of DRAT, which covered 6006 ha, was constructed at a cost of \$15.1 million. Stage II (1986-1994) included the expansion to 12,170 ha at a cost of approximately $\$ 44.5$ million. Currently, DRAT covers approximately 28,000 ha, of which 10,000 ha was included in the system of irrigation in 2003, when the Canal Oeste Tramo II was constructed at a cost of $\$ 2.5$ million.

The total investment in the DRAT infrastructure is estimated at $\$ 67$ million and benefits approximately 1125 families who produce mainly sugarcane, fodder, rice and fish from fish farms (400 ha of ponds), generating income of approximately $\$ 163.7$ million in the zone. The producers in the area pay SENARA a fixed rate of $\$ 42.5 /$ ha/year. The need to develop a tariff system based on volume used has been proposed; however, the social and economic conditions in the area have made it difficult to implement in the short term.

In addition, financial resources of $\$ 13.7$ million are being negotiated to construct stage IV of DRAT, which consists in the continuation of the Southern Canal and the distribution network of the Lajas and Abangares subdistricts, which would benefit about 155 families and would irrigate an additional 8800 ha.

IRRIGATION AND DRAINAGE OF SMALL AREAS (PARD) This system is promoted by SENARA and corresponds to requests made by associations of producers, individual producers or state institutions. SENARA is in charge of facilitating the process and, in some cases, constructing the irrigation canal. However, these are not state property but belong to the producers, who are in charge of properly maintaining the irrigation system. Currently, as can be seen in Table 6.8, 95 projects are in operation using pressurized systems of irrigation (drip, micro-sprinkling or

Table 6.8. Costa Rica: irrigation and drainage of small areas in operation by region. (From SENARA, 2005.)

\begin{tabular}{lccc}
\hline Region & Number of projects & Area (ha) & Number of families \\
\hline Brunca & 5 & 203.4 & 103 \\
Chorotega & 24 & 256.7 & 251 \\
Central Occidental & 29 & 1189 & 909 \\
Central Oriental & 12 & 337.5 & 360 \\
Huetar Norte & 7 & 445 & 226 \\
Pacífico Central & 18 & 254.8 & 174 \\
Total & 95 & 2686.4 & 2023 \\
\hline
\end{tabular}


sprinkling), which include an area of 2686.4 ha and benefit 2023 families who mainly cultivate vegetables, root crops, tubers, decorative plants and prickly pears. The majority use is of surface water; it is estimated that less than $3 \%$ uses groundwater.

The areas where DRAT and PARD operate include approximately $30,686.3 \mathrm{ha}$ and the total water demand is estimated at $35.2 \mathrm{~m}^{3} / \mathrm{s}$. Of this total demand, the Ministry of Environment and Energy (MINAE) has granted 1240 concessions for exploiting surface and groundwaters for agricultural use; less than $3 \%$ of the water in Costa Rica that is utilized for irrigation comes from groundwater.

In terms of short-, medium- and long-term investments, the expansion of DRAT and PARD is planned in the short term, which would be financed by the Central American Bank of Economic Integration (BCIE). In order to resolve future long-term water needs for domestic consumption, irrigation and tourism in the dry Pacific region of the country, studies are being conducted to consider building two multi-purpose dams in the Piedras and Tempisque rivers that would permit the utilization of rainwater and would reduce pressure on groundwater.

\section{Panama ${ }^{7}$}

Irrigation is relatively new in Panama. It is used in the production of three main groups of crops: traditional (rice, sugarcane and banana); vegetables and fruit for domestic consumption; and non-traditional export crops. Its purpose is to complement the rainfall conditions that prevail in the country, and its importance is growing along with economic liberalization, given the new opportuities in foreign and domestic markets.

Irrigated areas expanded from approximately 22,000 ha in 1970 to nearly 40,000 ha in 1990. A large part of this growth took place in the 1970s, with an approximate increase of 13,000 ha, principally in two state-owned companies (COBAPA and La Victoria Sugar Refinery). However, nearly 12,000 ha stopped being irrigated between 1990 and 1997, the majority of which was part of the state and public irrigation systems. This was a consequence of economic stagnation at the beginning of the 1990s and of the deterioriation and subsequent abandonment of agricultural projects on state farms and of public irrigation systems.

There is more than 270,000 ha of arable land in the country with soils and topography that could benefit from irrigation. Of this, approximately 71,500 ha has soil that is appropriate for irrigation and there is an adequate supply of water for irrigation, even in the dry season. All of this land could benefit from supplementary irrigation during the rainy season and would produce another cycle of crops if irrigation with surface water was practised during the summer. Despite this, Panama has not taken advantage of its irrigation potential. Currently, only 27,475 ha is under irrigation (Table 6.9), leaving dry about 44,000 ha of the land that is suitable for irrigation.

The majority of the 27,475 ha under irrigation is located in Coclé (12,963 ha), Veraguas (4478 ha) and Chiriquí ( $3288 \mathrm{ha})$. A system of gravity irrigation is used in $72 \%$ of the cultivated area $(19,871.2$ ha), mainly for rice cultivation, and 
Table 6.9. Panama: land surface under irrigation by province and technique. (From National Department of Rural Engineering and Irrigation, Ministry of Agricultural Development, 2005.)

\begin{tabular}{lccccc}
\hline & \multicolumn{5}{c}{ Irrigated area (ha) } \\
\cline { 2 - 6 } Province & Gravity & Sprinkler & Drip & Micro-sprinkler & Total \\
\hline Chiriquí & $1,716.6$ & 70 & 671.4 & 830 & 3,288 \\
Veraguas & $1,301.7$ & $3,115.7$ & 59.6 & 1 & 4,478 \\
Herrera & 50 & - & 877.7 & 6 & 933.7 \\
Coclé & $12,747.8$ & - & 209.2 & 6 & 12,963 \\
Panamá & $1,642.5$ & 97.5 & 28.5 & 109.6 & $1,878.1$ \\
Capira & 83 & 96 & 16.5 & 68.59 & 264.09 \\
Chepo & $1,559.50$ & 1.50 & 11.96 & 41 & $1,613.96$ \\
Los Santos & 770.2 & 18.5 & $1,258.6$ & 9 & $2,056.2$ \\
Total & $19,871.2$ & $3,399.2$ & $3,133.4$ & $1,071.2$ & 27,475 \\
\hline
\end{tabular}

other techniques are used to a lesser degree: sprinklers (12.4\%), drip (11.4\%) or micro-sprinklers (3.9\%, in cantaloupe and watermelon crops). Only in the provinces of Herrera and Los Santos is groundwater used for irrigation, reaching some $1122 \mathrm{ha}$, which is $4 \%$ of the total irrigated area. Groundwater is used only for private and individual projects, and the National Environmental Authority (ANAM) must grant a concession for that activity. The remaining 96\% of the area is irrigated by surface water.

Table 6.10 shows the new irrigation projects that were built between 1998 and 2004 (e.g. Boquete and Arco Seco projects) and the systems that have operated since 1972 and have been in a process of reconstruction since 1998 (e.g. public use irrigation). These systems cover approximately 5283 ha and benefit about 937 families in the provinces of Herrera, Los Santos, Chiriquí, Coclé and Veraguas. The irrigation systems for public use are administered independently by the users' associations who receive technical assistance and supervision by the Ministry of Agricultural Development. The associations that use gravity

Table 6.10. Panama: irrigation projects, number of beneficiaries and land area by province, 2005. (From National Department of Rural Engineering and Irrigation, Ministry of Agricultural Development, 2005.)

\begin{tabular}{llcc}
\hline Project & Province & Land area (ha) & $\begin{array}{c}\text { Number of } \\
\text { beneficiaries }\end{array}$ \\
\hline $\begin{array}{l}\text { Agro-exportation of } \\
\text { Azuero }\end{array}$ & Herrera and Los Santos & 2113 & 383 \\
$\begin{array}{c}\text { Agro-exportation of } \\
\text { Boquete }\end{array}$ & Chiriquí & 270 & 114 \\
$\begin{array}{c}\text { Irrigation systems for } \\
\text { public use }\end{array}$ & $\begin{array}{c}\text { Coclé, Herrera, Veraguas } \\
\text { and Los Santos }\end{array}$ & 2900 & 440 \\
Total & 5283 & 937 \\
\hline
\end{tabular}


systems charge their members a fee of $\$ 20 / \mathrm{ha} /$ season. ${ }^{8}$ The systems that require pumping of surface water charge a fee of $\$ 30-40 /$ ha/season. However, a revision of these fees is needed because they do not cover the necessary costs for maintenance and reinvestment in the irrigation systems.

Approximately $80 \%$ of the investment in Panama is from private funds and only $20 \%$ is invested by the state. The Ministry of Agricultural Development's expansion plans include the projected construction of six new irrigation projects and the conclusion of the reconstruction of the Irrigation Systems of Public Use located in the provinces of Coclé, Veraguas and Los Santos, which are being completely financed by the state with resources from the Development Trust Fund. The cost for remodelling of this system is $\$ 12.5$ million. The estimated budget expense for five of the new projects is approximately $\$ 300$ million.

In 2005, the government was to seek bids for building the Remigio Rojas Irrigation project in Chiriquí province, in the western region of the country. This project would incorporate 3200 ha into intensive irrigated production, basically directed to agro-exportation. The project comprises the construction of public and hydrological works; irrigation systems on farms, including local irrigation systems; postharvest plants, as well as the development of specialized technical assistance programmes; and technological transfer and implementation of marketing programmes through a 3-year programme of continual accompaniment by the company that is awarded the project.

In Panama, the selection of projects for state investment is based on the recommendations found in the National Irrigation Plan, a regulating, guiding and planning instrument for the development of the irrigation subsector. This plan was prepared through the initiative of the Ministry of Agricultural Development in 1977, in consultation with Utah State University, and was financed by the Inter-American Development Bank. The plan contains a database of projects for irrigation investment in which the most suitable areas for irrigated agricultural development have been prioritized, beginning with the parameters related to soil characteristics and water availability.

\section{Institutional Framework}

Within the framework of Central American integration, there were interesting initiatives in the late 1980s such as subscribing to the Central American Agreement for Environmental Protection, which was created by the Central American Environment and Development Commission (CCAD); it later became an organization of the Central American Integration System (SICA), which had been established previously in the Tegucigalpa Protocol. ${ }^{9}$

Various initiatives have been developed in Central America for the purpose of harmonizing the policies and legislation for water management in the region. In 1994, the Central American Water Agreement was signed, which sought the efficient use of water resources based on criteria of fairness and justice. In the agreement, water was considered the 'germ of life, source of development and peace, and a public good with economic value', and the interests of the involved actors must therefore be considered in its management. Also, in the same year, 
the Central American Ecological Summit for Sustainable Development was held in Nicaragua, where the Alliance for Sustainable Development (ALIDES) was signed in which the formulation of policies and legislation regarding water management and conservation was established as a priority (Aguilar, 2005).

In 1999, CCAD prepared the Central American Regional Environmental Plan (CAREP), which contemplates integrated management as one of its principle policies: social, economic and ecological, equitable access, and the promotion of shared responsibility in the management of water. Its objectives included an attempt to guarantee the protection of water sources and to assure the long-term provision of the adequate quantity and quality of water in order to define uses and to promote the total economic valuation of water resources.

In March 1997, CCAD, together with the Regional Committee on Hydraulic Resources $(\mathrm{CRRH})$, prepared a proposal for the Central American Action Plan of Integrated Water Resource Management (PACADIRH). This proposal was understood to be a group of strategies and actions to 'direct and harmonize the joint development of the water-related wealth enjoyed by the Central American Isthmus, in harmony with the principles of sustainable development'. In 2004, the updated version of CAREP (2005-2010) included the topic of water within the theme of prevention and control of environmental contamination in addition to being considered a transversal theme for action.

In spite of the efforts made in the region, water management is still considered sectorially, depending on whether its use is for irrigation, domestic consumption, industry or energy production. No differentiation is made between surface water and groundwater. No specific law exists in any country about regulating the management of groundwater. Rather, the existing policies and laws have been established to regulate individual uses. At the moment, the Central American countries lack a policy for integrated water management. Only Costa Rica (1942), Honduras (1927) and Panama (1996) have a General Water Law (Table 6.11). These, however, contain no vision of integrated management.

In the countries of the region, with the exception of Panama and Belize, water administration is the responsibility of the Environmental Ministries. In the case of Panama, responsibility falls on the National Environmental Authority (ANAM) and in the case of Belize it is not defined. Although the administration is defined in almost every country, in practice it has not functioned. Due to the lack of clear laws and strong institutions to assume this role, administration continues to be sectorial and falls on the water users.

The institutional framework has been characterized as fragmented and dispersed, with badly defined roles and functions, and with overlapping responsibilities. In terms of groundwater, policies and laws in countries such as Costa Rica and Panama have focused on regulating its use through a system of concessions.

However, given the need to update the normative and legal frameworks, four countries - Costa Rica, Nicaragua, Honduras and Guatemala - are currently preparing proposals for new laws, which are being discussed or are about to be discussed in the respective congresses. In Panama, a process of public bidding is in process for the preparation of a new water law, and the Watershed Law is being regulated. In Belize and El Salvador, discussions have begun to prepare the necessary conditions for drafting a water law and national water plans. 
Table 6.11. Central America: current water legislation and water law projects. (From Aguilar, 2005.)

\begin{tabular}{|c|c|c|}
\hline Country & Current legislation & Water law project \\
\hline Belize & $\begin{array}{l}\text { Water and Sewerage Ordinance, Chapter 185, } 1971 \\
\text { Water and Sewerage Sanitary Instrument, No. 29, } \\
\quad 1982 \\
\text { Environmental Protection Act, No. 22, } 1992 \\
\text { Public Health Ordinance, Chapter 31, } 1943 \\
\text { National Lands Act, No. 83, } 1992 \\
\text { Water Industry Act, Chapter 222, } 1993\end{array}$ & Not found \\
\hline Costa Rica & $\begin{array}{l}\text { Law No. 276, General Water Law, } 1942 \\
\text { Law No. 1634, Potable Water Law, } 1953 \\
\text { Law No. 5395, General Health Law, } 1973 \text {, and its } \\
\text { reforms } \\
\text { Environmental Law No. } 7554,1995 \\
\text { Law No. } 2726 \text { to Create AyA, } 1961 \\
\text { Law No. } 7779 \text { for Land Use, Management and } \\
\text { Conservation, } 1998 \\
\text { Regulation 25992-S for the quality of drinking water, } \\
\quad 1997 \\
\text { Regulation 26042-S MINAE for the disposal and } \\
\text { reuse of wastewater } \\
\text { Environmental Tax for Effluents, Decree } \\
\text { No. 31176-MINAE }\end{array}$ & $\begin{array}{l}\text { Water Resources } \\
\quad \text { Law Project, } 2004\end{array}$ \\
\hline El Salvador & $\begin{array}{l}\text { Integrated Water Resource Management Law, } 1981 \\
\text { Water Quality Bylaw, Flow Control and Protected } \\
\text { Areas, Decree No. 50, } 1987 \\
\text { Irrigation and Drainage Law } \\
\text { Administration of Aqueducts and Sewers } \\
\text { Systems Law } \\
\text { Environmental Law, Legislative Act 233, } 1998 \\
\text { Special Bylaw on Residual Waters }\end{array}$ & Not found \\
\hline Guatemala & $\begin{array}{l}\text { Dispersed legislation in different normative bodies. } \\
\text { Among them: } \\
\text { Civil Code, Act } 1932 \\
\text { Environmental Protection and Improvement } \\
\text { Municipal Code } \\
\text { Health Code }\end{array}$ & $\begin{array}{l}\text { General Water Law } \\
\text { Project, } 30 \text { August } \\
2004\end{array}$ \\
\hline Honduras & $\begin{array}{l}\text { Law for the Use of National Waters, April } 1927 \\
\text { Law for Drinking Water and Sanitation, } 2003\end{array}$ & $\begin{array}{l}\text { General Water Law } \\
\text { Project, } 2004\end{array}$ \\
\hline Nicaragua & $\begin{array}{l}\text { Law 440, 'Suspension of Water Use Concessions', } \\
2003\end{array}$ & $\begin{array}{l}\text { General Water Law } \\
\text { Project, January } \\
2005\end{array}$ \\
\hline Panama & $\begin{array}{l}\text { General Water Law, } 1966 \\
\text { Law 41, Panama Canal River Basin, } 1998 \\
\text { Law 44, Special Administrative Regime for the } \\
\text { Management, Protection and Conservation of } \\
\text { Watersheds, } 2002\end{array}$ & Not found \\
\hline
\end{tabular}


In Nicaragua, the proposed law was generally approved, which places it in an advanced position within the legislative procedure; however, as in Costa Rica, it is subordinate to policy priorities and to the dynamics of the local power structures. Given the serious political crisis that this country is going through, as well as being delayed while the Central America Free Trade Treaty with the USA was being discussed, it is very doubtful that the project will be voted for by Congress in the next few months.

In the case of Costa Rica, by February 2004 the Water Department of the Ministry of Environment and Energy had granted 899 concessions throughout the country. Of these concessions, $0.9 \%$ corresponds to groundwater extraction and $29.3 \%$ is for irrigation (Table 6.12). This is due to the lack of existing control on the part of the Ministry, thereby facilitating the illegal extraction of water.

In other countries of Central America, such as Nicaragua and Guatemala, regulations are lacking, resulting in the uncontrolled extraction of water. In Guatemala, groundwater is managed by a private company. In Honduras, there are no controls regarding the exploitation of aquifers; therefore, it is possible that safe extraction limits are being exceeded.

\section{Conclusions}

Central America appears on the surface to be a water-abundant region. However, as described elsewhere (e.g. Shah, Chapter 2, this volume), population and water supply do not overlap. Further, supply is not consistent throughout the year, and there are often problems with quality due to sedimentation and pollution. These issues, combined with growing populations, have already brought out general challenges for supplying water for agricultural, domestic and industrial purposes throughout the region.

However, unlike the other regions covered in this book, there is currently little groundwater used in agriculture in any of Central America's countries.

Table 6.12. Costa Rica: concessions granted by the Water Department of the Environmental Ministry by type of source and use, February 2004. (From Water Department, Environmental Ministry of Costa Rica.)

\begin{tabular}{lccc}
\hline Type of use & Surface water & Wells (underground) & Total \\
\hline Agricultural/fishing & $28,793.6$ & 162.3 & $28,955.9$ \\
Agro-industrial & $6,608.9$ & $1,693.8$ & 8302.7 \\
Irrigation & $121,118.0$ & $2,495.5$ & $123,613.5$ \\
Human consumption & $3,958.8$ & $1,556.5$ & $5,515.2$ \\
Commercial & 83 & 98.2 & 181.1 \\
Industry & $4,218.9$ & 1,956 & 6,175 \\
Hydraulic energy & $722,965.6$ & & $722,965.6$ \\
Tourism & $2,974.3$ & 568.2 & $3,542.5$ \\
Total & $890,721.1$ & $8,530.5$ & $899,251.5$ \\
\hline
\end{tabular}


Figures collected for this chapter show a total of less than 50,000 ha under groundwater irrigation, with most of that figure in Guatamala. At least three factors help to explain this outcome. First, there is relatively little irrigation in the region in general. Second, when irrigation does exist it is (in rural areas) usually supplied through relatively abundant surface water, which is generally of lower extraction cost than groundwater. Third, the main aquifers in Central America are generally located under metropolitan areas or, in other words, metropolitan areas have tended to grow over the main aquifers.

To date, the main use of groundwater in Central America is for household consumption, followed by industry and tourism activity. Still, the experience of Central America, both in terms of its overall groundwater situation and with reference to its urban use, highlights many of the stories, issues and challenges brought up elsewhere in this volume.

First, groundwater use in Central America seems to be following the development paradigms described by Shah and Kemper (respectively, Chapter 2 and Chapter 7, this volume). Agricultural groundwater use is generally still in stage I of their typologies, the stage before significant problems have emerged. While movement down the agricultural groundwater development path will likely vary from country to country and within countries, urban and industrial use surrounding metropolitan areas is already in stages II or III, and aquifers are showing clear signs of stress.

Second, as in most of the other regions described in this book, Central America has a great vacuum regarding information on groundwater. This applies to information on the resource itself as well as on its use. Failure to create, centralize and share information means there is little basis for management and decision-making in the already stressed urban areas, as use in some areas could lead to scarcity in the future. Moreover, there is only limited information on the potential for additional agricultural development, as the information that is available is not always consistent across countries, making it difficult to establish a regional information and lessons-sharing system.

Third, as in most of the other regions described in this book, the majority of Central American countries have either no water laws or only obsolete laws with little practical application. For this reason, the groundwater governance problems already occurring in South Asia and China are also occurring in Central American cities and may impact agriculture in the future. Connected to the governance problem is the growth of cities, particularly capital cities, over the highest potential aquifers. While use of groundwater in urban areas has clear benefits, the absence of land regulation and planning has meant that many cities have expanded into recharge areas, threatening the water that helped the cities' existence in the first place. Lack of control over industrial and human contaminants is increasingly threatening water quality. Uncontrolled agricultural chemical use is high throughout the region with concomitant risks to groundwater quality through percolation. To date, measurable concentrations do not generally exceed permissible limits, but pollutants are being detected, meaning that concentrations are increasing.

Clearly there has been no 'agricultural groundwater revolution' in Central America; nor is there likely to be one in the future simply because of climatic 
conditions. None the less, there are critical connections between agriculture and groundwater in Central America, though the importance of these connections is not the same as in regions where direct agricultural use is much higher. It is the study of this contrast that can help us to understand how broad the connections between agriculture and groundwater can be.

\section{People Interviewed}

- $\quad$ Ricardo Tompson, Ministry of Agriculture, Belize.

- Antonio Gaitán, Coordinator of DIAPRYD, PLAMAR-Ministry of Agriculture and Livestock (MAGA), Guatemala.

- Alejandro Flores Bonilla, Director of the Division of Irrigation and Drainage of the Ministry of Agriculture and Livestock, El Salvador.

- Oscar Cosenza, Director, General Department of the Secretariat of Agriculture and Livestock (SAG), Honduras.

- $\quad$ Rigoberto Reyes, Irrigation and Drainage Unit, Ministry of Agriculture and Forestry (MAG-FOR), Nicaragua.

- Marvin Coto, Director of Operations, National Irrigation and Drainage System (SENARA), Costa Rica.

- Héctor Elías Pérez, Director of the National Department of Rural Engineering and Irrigation, Ministry of Agricultural Development, Panama.

\section{Notes}

1 Based on information provided by Ricardo Tompson, Ministry of Agriculture in Belize.

2 Based on information provided by Antonio Gaitán, Coordinator of DIAPRYD, PLAMAR, Ministry of Agriculture and Livestock (MAGA).

3 Based on information provided by Alejandro Flores Bonilla, Director of the Department of Irrigation and Drainage of the Ministry of Agriculture and Livestock in El Salvador, September 2005.

4 Based on information provided by Oscar Cosenza, Director of the General Department of Irrigation and Drainage, Secretariat of Agriculture and Livestock (SAG), Honduras.

5 Based on information provided by Rigoberto Reyes, Irrigation and Drainage Unit, Ministry of Agriculture and Forestry (MAG-FOR), Nicaragua.

6 Based on information provided by Marvin Coto, Director of Operations, National Irrigation and Drainage Service (SENARA), Costa Rica.

7 Based on information provided by Héctor Elías Pérez, Director of the National Department for Rural Engineering and Irrigation, Ministry of Agricultural Development, Panama, September 2005.

8 The number of seasons will depend on the kind of crop, if there are periods of rotation of one, two or more times a year.

9 'The Central American Environment and Development Commission (CCAD) has tried to interject the environmental variable into the regional integration process so that it would be taken into consideration in the economic, social or any other kind of decision'. Madrigal, P. (1977) Aplicación y Cumpliminto de la Legislación Ambiental en Centroamérica. Revista Parlamentaria 5(3) 152. 


\section{References}

Aguilar Grethel (2005) Estado del Marco Normativoy Legal delAgua en Centroamérica. Documento borrador. GWP-BID.

Aquastat (2001) Land and Water Agriculture. FAO Info System on Water and Agriculture.

CEPAL (2003) Anuario Estadístico de América Latina y el Caribe. Santiago de Chile, Chile.

Choza (2002) Prevención y Control de la Contaminación de Aguas Subterráneas en Acuíferos Urbanos. Programa Asociado de la Global Water Partnership de Centroamérica.

CIEUA (1998) Evaluación de recursos de agua de la República de El Salvador, Distrito de Mobile y Centro de Ingeniería Topográfica, El Salvador.

CRRH-SICA, GWP-CATAC-UICN (2002) Diálogo Centroamericano sobre Agua y Clima. San José, Costa Rica.

GWP-GlobalWater Partnership-Central America (2005) Situación de los Recursos Hídricos en Centroamérica: Hacia una Gestión Integrada. San José, Costa Rica.

Hetch, G. (1989) Calidad de las aguas del acuífero regional Las Sierras. Internal report. INETER, Dpto. de Hidrogeología.

Leonard, J. (1987) Recursos Naturales y Desarrollo Económico en América Central. Un Perfil Ambiental Regional. International Environment and DevelopmentInstitute(Institutolnternacional para el Ambiente y el Desarrollo).

Losilla, M., Rodríguez, H., Schosinsky, G., Stimson, J. and Bethune, D. (2001) Los Acuíferos Volcánicos y el Desarrollo Sostenible en América Central. Editorial de la Universidad de Costa Rica. Primera Edición.

Programa de Reconversión Productiva de Agricultura y Alimentación (PARPA). Información compilada con base en información suministrada por PLAMAR-MAGA 2003-2004.
Reynolds, J. (1992) Contaminación por nitratos en las aguas subterráneas de la Cuenca del Río Virilla. En: Primer Simposio Nacional sobre Plaguicidas: Problemática y Soluciones. San José, Costa Rica, octubre 1992.

SENARA/BGS (Servicio Nacional de Aguas Subterráneas y Avenamiento) (1989) Continuación de la investigación hidrogeológica en la zona norte y este del Valle Central, Costa Rica. Informe final 1984-87. SENARA, Informe Técnico No.165. San José, Costa Rica.

SENARA/BGS (1998) Continuación de las Investigaciones Hidrogeológicas en el Valle Central de Costa Rica. Servicio Nacional de Aguas Subterráneas, Riego y Avenamiento/ British Geological Survey; Final report. SENARA, San José, Costa Rica.

SENARA (2005) Area de operaciones: proyectos en diseño y en funcionamiento.

SG-SICA (2001) Plan Centroamericano para el Manejo Integrado y la Conservación de los Recursos del Agua.

Silvel, E., G. Gellert, E. Pape and E. Reyes (1997) Evaluación de la sostenibilidad. El caso deGuatemala, FLACSO/WWF, Foro Mundial para la Vida Silvestre.

TAHAL (1990) Plan Maestro de Abastecimiento de Agua Potable de la Gran Área Metropolitana. Tomo III, Aspectos Hidrológicos e Hidrogeológicos. Instituto Costarricense de Acueductos y Alcantarillados. San José, Costa Rica.

World Bank (2005) The Little Green Data Book.: From the World Development Indicators. Available at http://www.oas. org/USDE/publications/Unit/oea34s/begin. htm \#Contents 